\title{
ReSearchArticle
}

\section{Management of root rot disease in French beans (Phaseolus vulgaris) by using microbial consortium}

\author{
S. Malathi
}

\section{SUMMARY}

Root rot disease of beans is caused by Rhizoctonia solani. Biocontrol agents were tested for their antagonistic activity against root rot pathogen Rhizoctonia solani. Among the tested isolates, Trichoderma viride recorded the maximum (86.04\%) inhibition on the mycelial growth of pathogen followed by Pseudomonas fluorescence which recorded 79.12 per cent inhibition on the mycelial growth. Treatment with (SA+ST with P. fluorescens $+T$. viride) + Neem cake was recorded maximum (78.55\%) disease reduction in the field condition with the yield of $2654 \mathrm{~kg} / \mathrm{acre}$. Combined application of biocontrol agents having ability to reduce root rot disease in French bean and increase the yield siginificantly.

Key Words : Beans root rot, Rhizoctonia solani, Trichoderma sp., Pseudomonas sp., Biological control

How to cite this article : Malathi, S. (2019). Management of root rot disease in French beans (Phaseolus vulgaris) by using microbial consortium. Internat. J. Plant Sci., 14 (1): 28-32, DOI: 10.15740/HAS/IJPS/14.1/28-32, Copyright@ 2019: Hind Agri-Horticultural Society.

Article chronicle : Received : 18.10.2018; Revised : 07.12.2018; Accepted : 17.12.2018 